\title{
Energy policy and conservation planning in Sweden: a longitudinal evaluation
}

\author{
Mattias Legnér and Gustaf Leijonhufvud \\ Department of Art History, Conservation, Uppsala Universitet Campus Gotland, \\ Visby, Sweden, and \\ Martin Tunefalk \\ Statens Historiska Museer, Stockholm, Sweden
}

\begin{abstract}
Purpose - Sweden, like other countries, has set ambitious national targets for both energy efficiency and conservation of heritage values in the built environment. However, how these policies are implemented on a local level and how they affect each other is not known. This study aims to argue that extensive energy-saving policies can have unintentional impacts not just on the built environment but also on conservation practice. Design/methodology/approach - By using a longitudinal approach, the aim is to investigate the possibilities of conserving the built environment when policies for increased energy efficiency are implemented in existing urban areas. The methodology used is qualitative, applying a combination of study of public records, policy documents, interviews with public officials and ocular investigation of buildings in three areas located in two different municipalities.

Findings - The study suggests that extensive refurbishments not only have effects on the character of an area, but in extension, affect how urban planners and local authorities approach the development in the same area. Urban areas affected by extensive retrofits in the past seem to be managed in less detail, leaving existing policy measures on both energy and heritage untapped.

Research limitations/implications - This is a study concerning two Swedish municipalities. Furthermore, it is limited to one specific policy measure, energy-saving subsidies provided in the 1970s and 1980s. The generalisability of the findings may, therefore, be limited. Despite this, the findings provide an important indication of the relationship between energy-saving policies in the past and urban planning practice of existing urban areas today, as well as the importance of alignment between policy-making and implementation. Practical implications - Policy instruments for the building stock and the practice of conservation planning have not worked well together. Due to local practice, energy subsidies provided in the 1970s and 1980s still today have a negative effect on both heritage conservation and energy efficiency in existing areas.

Social implications - There is a discrepancy between expectations and outcome of policy measures. National decision-makers overestimate the possibilities to control the development on a local level, for both energy efficiency and heritage values. By examining an innovative set of sources, acknowledging long-term effects and entanglements of policies and practice, this study contributes to a better understanding of the complexity of different values in the built environment.

Originality/value - By comparing the share of approved applications, as well as completed energy retrofits, this study demonstrates that the effects of the national energy subsidy policy differed significantly between urban areas. Areas with a high degree of approved subsidies also had a high degree of retrofits, suggesting that the policy had intended effects. In these areas, the number of retrofits were also significantly higher than the number of subsidies. This was not the case where energy subsidies were fewer, which indicates that energy retrofits are performative, meaning that they accelerate further retrofits in the same area.
\end{abstract}

Keywords Energy efficiency, Built heritage, Policy-making, Conservation, Swedish urban planning Paper type Research paper

This work was supported by the Swedish Energy Agency under Grant \#40417-1: "An evaluation of previous policies on energy efficiency and their effects on energy use and historical values, Sweden 1974-2014".

Received 5 November 2019 Revised 2 March 2020 14 April 2020

Accepted 14 April 2020 


\section{Introduction}

Between 1974 and 1983, energy saving subsidies were provided in large scale in Sweden to improve the energy efficiency of the residential building stock. Following the oil crisis, national planning policy was strongly oriented towards potentials for energy savings. Measures entitled to subsidies were, e.g. new heating systems, additional insulation and new windows. These governmental efforts can be described as a success: the Swedish building stock was transformed from being heavily dependent on oil to become one of the countries with smallest carbon footprint per useful floor area in Europe (Economidou et al., 2011). However, as previous evaluations have pointed out, the extensive retrofit measures also had an immediate detrimental impact on architectural values in existing buildings (e.g. Antell and Paues, 1981).

Evaluations of public policy in the building sector have tended to look at the latest policy in isolation, with a negligence towards long-term consequences. Notwithstanding the long experience of energy efficiency programmes, there is a lack of knowledge of their long-term impacts on the built heritage. Also, the way energy efficiency policies have been implemented and integrated with existing planning policy on the local level is not well known, despite more than 40 years of experience.

This study argues that energy efficiency policies have had far-reaching and enduring impact not only on the fabric of individual buildings but also on the practice of conservation planning. The article demonstrates how extensive energy retrofitting in two municipalities in Sweden, spurred by national energy efficiency programmes launched in the wake of the 1970s oil crisis, still today affects how urban planners and local authorities approach the development of affected areas. The overall aim of the paper is to understand the long-term impacts of energy efficiency policies on the conservation planning in historic urban areas.

\section{Literature review}

Sweden has had a national strategy for energy-efficient renovation of buildings since 2013. The aim is to support a development where the use of fossil fuels in buildings should have reached zero by 2050. In 2017, residential buildings and services represented 39 per cent of all energy use in Sweden. Heating and hot water represents about 60 per cent of the energy used in residential buildings and facilities. As the pace of renovation of this category of buildings is relatively slow, the Swedish Energy Agency recently concluded that it will become difficult to reach the goal of zero emissions by 2050 if the rate does not accelerate (Energimyndigheten, 2019, pp. 6-7). Increased energy efficiency in buildings, thus, remains an important policy goal. The Swedish Government adopted new climate policy in 2017, including a new goal of zero net emissions of greenhouse gases by 2045 (Govt. Bill 2016/17:146). Achieving this target will require a transition of the energy system, including continued and accelerated energy efficiency of existing buildings, especially in relation to the specific challenges of the impending smart grid (SOU 2017:2, p. 185).

Recent studies indicate that there are greater problems than just a slow rate of energyefficient renovations in Sweden. Municipalities have witnessed of the limited possibilities to protect architectural values in processes of building and renovation (Riksantikvarieämbetet, 2017, 2018), and studies from Gothenburg have indicated low ambitions of developers regarding both conservation and energy efficiency (Femenías et al., 2020). The conservation of the character of buildings has widely been understood to be in opposition to increased energy efficiency in buildings, but in recent discourse, there has been a shift in viewpoints towards a less antagonistic relationship (Webb, 2017).

Our own research shows, however, that in recent history, conservation interests has been pitted against the goals of increased energy efficiency (Legnér and Leijonhufvud, 2019). In Sweden, building conservation has had to step aside for policies ultimately designed to boost 
the level of employment in the building sector and to upgrade the housing stock (Tunefalk and Legnér, 2019a). A study of Arsta (a district of multi-family buildings built in the 1940s) in Stockholm showed that façade insulation improved energy efficiency considerably, while at the same time, permanently diminishing the architectural values and thus giving the buildings weaker legal protection (Tunefalk and Legnér, 2019b). Even when carried out in a seemingly sensitive way and according to guidelines, thermal insulation of facades has diminished the architectural values of even modern buildings.

Previous research has argued that energy efficiency programmes in general have been insufficiently evaluated (Geller et al., 2006), that evaluations have tended to focus on narrow techno-economic indicators, i.e. "efficiency" (Rosenow et al., 2016), and that the feedback loop between evaluations and policy design remains to be closed (Vine, 2008). Accounts of how specific policies have evolved over time have proven to be useful for understanding challenges and opportunities, but long-term evaluations remain rare. Mallaburn and Eyre (2014) advocate an historical perspective and argue that the lessons learnt from 40 years of UK experience with energy efficiency policies were largely ignored in the formulation of the UK Green Deal. Rosenow (2012) used interviews and document analysis to understand the development of energy obligations in the UK. It is shown how the development of a certain policy can be analysed by looking at a broad set of contextual factors, such as institutional and discursive changes. An historical account of energy use in Norway (Sandberg et al., 2011) discusses how a narrow focus on efficiency in policy-making often has failed to deliver persistent energy savings. The above-mentioned studies reveal a promising potential for using a longitudinal perspective when evaluating energy efficiency programmes that this paper aims to explore further.

\section{Materials and methods}

Following the aim of investigating long-term effects of energy-saving policies on the practice of conservation planning, the study has been structured in two parts. First, the implementation of energy policies has been investigated in three urban areas in Sweden. Second, we have studied conservation planning of today in the same areas.

1) To identify long-term effects, subsidies provided to homeowners between 1974 and 1983 have been analysed. This was one of the earliest policy measures for energy efficiency in the built environment in Sweden and in Europe. It was also an extensive policy, possibly with substantial effects on the built environment.

Investigating the implementation of the policy in practice, initially, two urban areas were studied: Brynäs in Gävle and Visby intramural. These two areas soon demonstrated important differences in how the policy was implemented. This pointed to the importance of interpretation and implementation on a local level. To try whether differences occurred within the same municipality (i.e. with the same planning officials and local regulations), another area in Visby was added to the study: Visby villastad. This area was chosen for its similarities to Brynäs in regard to building year, style, social composition, etc. Comparing the three areas provides an opportunity to find whether the energy subsidies affected future conservation planning or if local policies and practices were determining in the two municipalities. A more detailed description of the areas is presented below (Plates 1-3).

To establish the rate and nature of approved subsidies for the different areas, the archives of the regional housing committees (länsbostadsnämnderna) in Gävle and Gotland have been studied. Gävle was chosen because it is a mid-size town and because it has a well-preserved archive of the regional housing committee, including records containing drawings for proposed renovations supported by subsidies on increased energy efficiency. In the case of Visby (and the vast majority of places in Sweden), such drawings have not been preserved. 


\section{IJBPA}

\section{Plate 1.}

Part of S:t Hansgatan i Visby intramural. There is a lack of thermal insulation to the exterior of walls, and few windows have been replaced in recent decades. Photo from 2017. Photographer: M. Legnér

\section{Plate 2.}

The same house as in Figure 2, photo from 2017 showing how the house recently having been thermally insulated of the facades, which have been replaced. The windows have also been replaced recently, altering the character of the house quite substantially. Photographer: G. Leijonhufvud
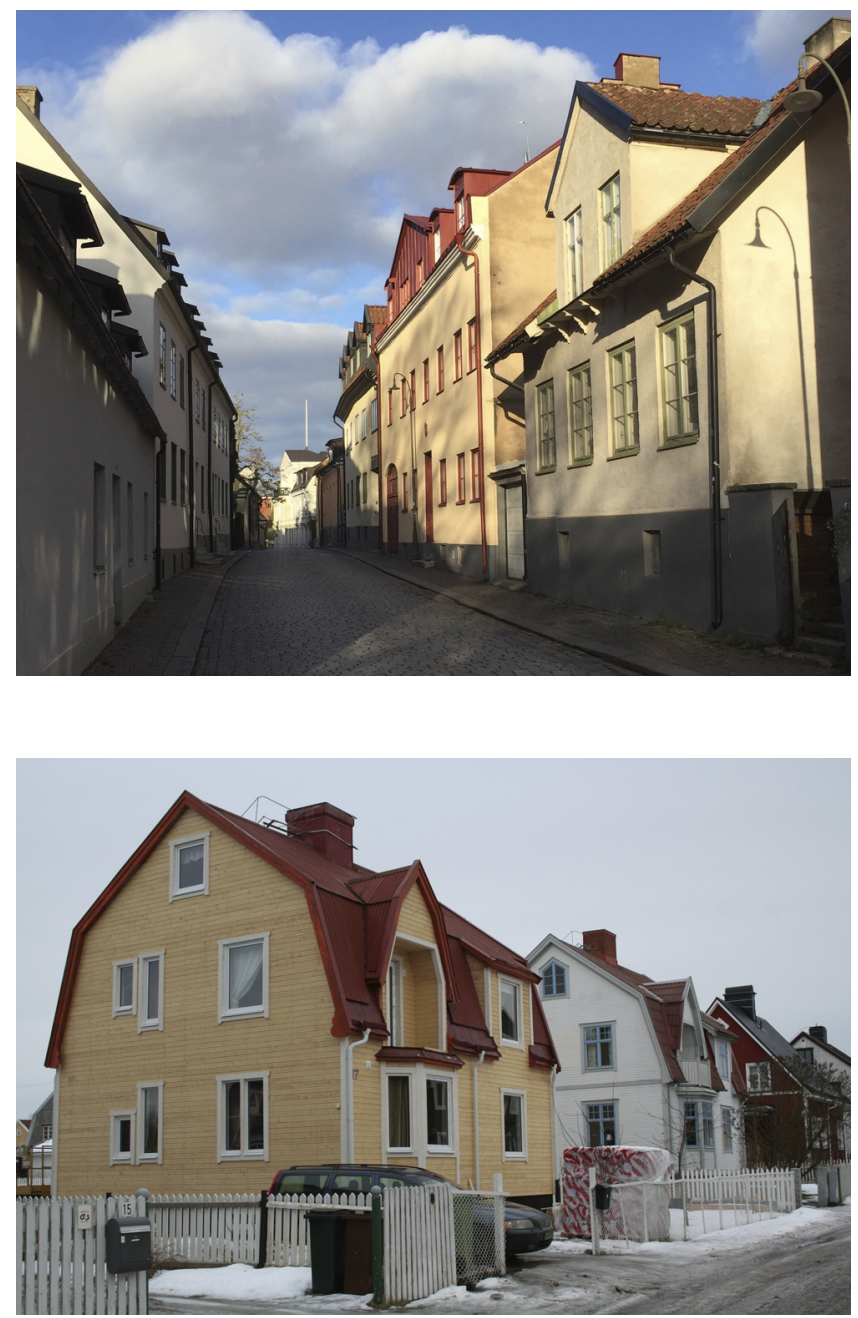

The architectural values of the area studied in Gävle were surveyed already in the 1970s and again in 1984, making it possible to follow the development over time. Visby was chosen for its internationally recognised cultural values and because it represents smaller towns in Sweden, especially when it comes to the areas outside of the city wall (Plate 1).

This paper is the first academic study of the work of regional housing committees. The committees assessed applications from homeowners in each county. In the archives, it is noted what kind of measures were included in each application, the name of the property and whether it was approved or not. These records allow us to determine to what extent energy subsidies were approved for each area. Measures were sorted into four categories in the regional housing committees: improved heating and ventilation system; connecting to district heating; installation of individual meter for hot water; and improved thermal insulation in walls, windows and joists. The latter of these is the only one affecting the exterior character of the building and therefore relevant for this study. Heating and ventilation systems can affect 


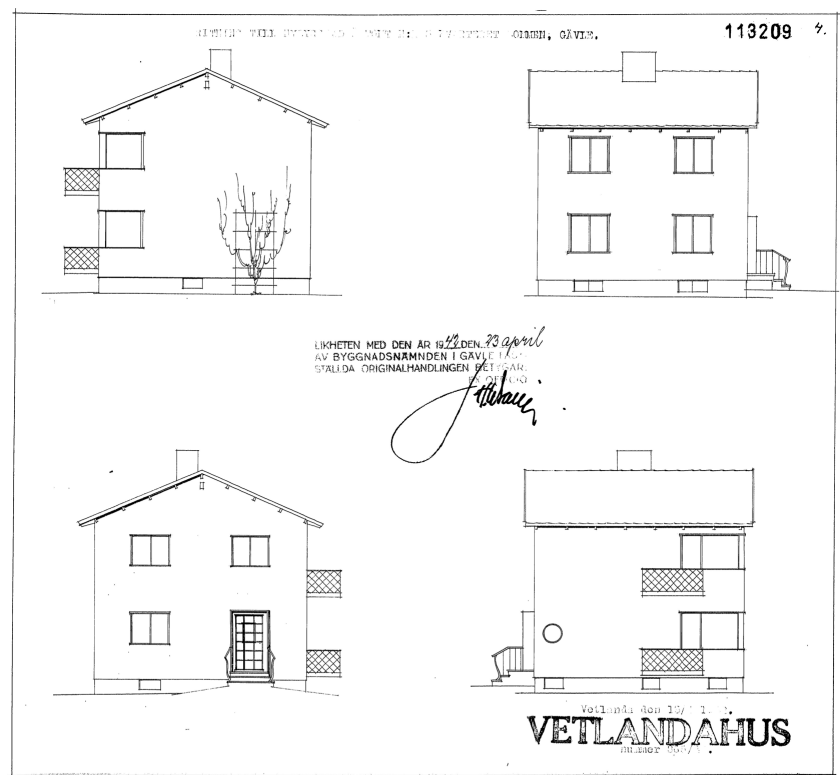

Source(s): Gävle municipality archive
Energy policy

Figure 1.

Residential house in Brynäs, built in 1942

the interiors, but this study is limited to the exteriors of buildings. The results are based on energy efficiency subsidies, targeting measures for improved insulation of walls and installation of new windows. The differences between the three areas are significant and provide a clear indication of local discrepancies.

At least in theory, most major exterior alterations to buildings demanded a permit issued by the municipality. To get a more detailed description of the subsidised measures, as well as to establish the rate of energy retrofits completed without support, a comprehensive study of all building permits for each area was conducted (Figure 2). The acts are located in the municipal archives. They are heterogeneous when it comes to the information value for this study, and as the study demonstrates, many exterior measures, although extensive, were not subject to audit.

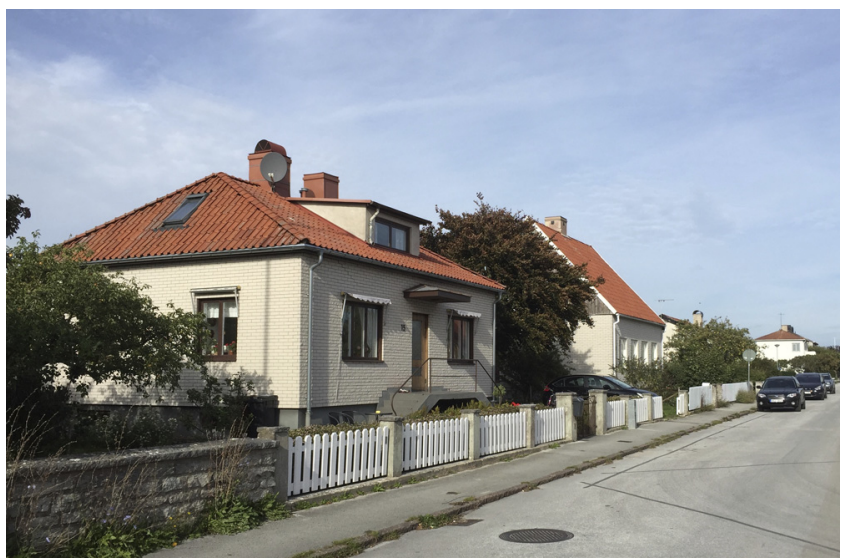

Plate 3.

Part of Polhemsgatan in Visby villastad, showing houses thermally insulated with bricks ("mexitegel") around 1980. Photo from 2017.

Photographer: M. Legnér 
IJBPA

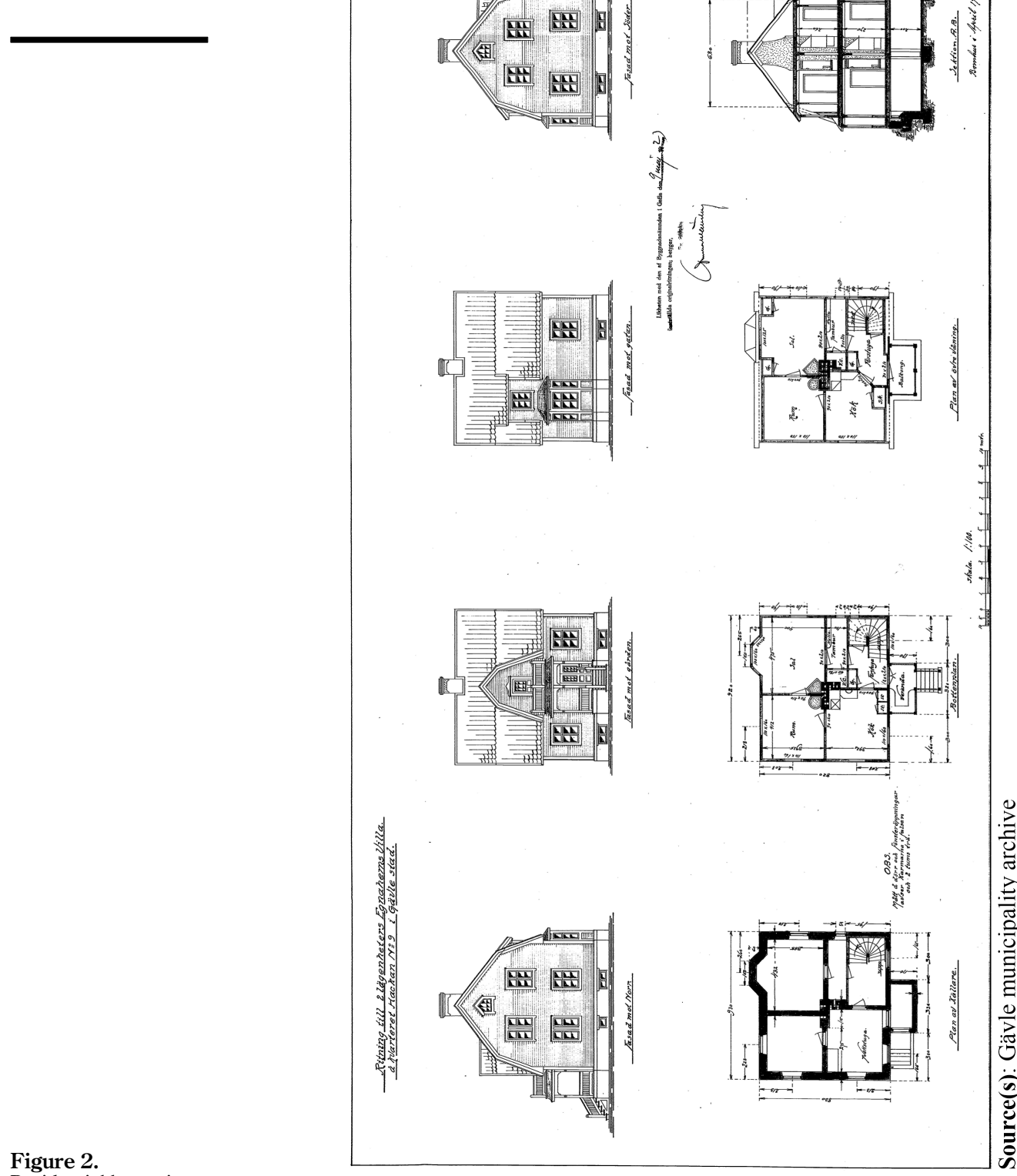

Residential house in

Brynäs, built in 1923 
To find whether approved alterations have actually been carried out, and to detect alterations carried out without consent from the municipalities, ocular observations have been made of each area. This also provides an opportunity to study the quality and extent of completed retrofits. Changes to a building can, of course, have a varying impact on the character of the area. The measures addressed in this study, i.e. additional thermal insulation and new windows, can vary in both extent and quality, affecting the character of the building, and in extension the area, in a varying degree. For example, additional insulation can be applied to a limited area of the façade and in a varying thickness. The quality of the craftsmanship is evident in details such as transitions between components and in the surface layer. Windows are provided in a wide range of qualities and styles, affecting the character of an old building differently.

2) The practice of conservation planning in the different areas has been studied using group interviews and local planning policies. Interviews were carried out with the city architects, regional and municipal conservation officers of both cities. In Visby, four experienced officials dealing with urban planning and conservation were interviewed: the city architect, a conservation officer handling building permits at Regional Gotland, one urban planner and one conservation planner from the county board of administration. In Gävle, three officials were included: the conservation officers of the municipality and the county board and the city architect. The interviews were conducted in two steps. First, while walking through the area, and second, as a seated group discussion, which was recorded and transcribed. The interviews consisted of open questions regarding planning and conservation in the specific area. A typical question, standing in front of a building, was: "What are your thoughts about the changes carried out on this property?" The answers were followed by follow-up questions, triggering a discussion on the practice of conservation planning in the area. The interviews were recorded and afterwards transcribed to alleviate the analysis of them.

The interview answers have been related to planning and building policies, including (for each city) comprehensive plans (översiktsplaner) and conservation policies and guidelines. Differences in conservation practise, derived from both interviews and studied policy documents, have been related to the degree of subsidised energy retrofits in the past. This combination of materials and methods allows us to understand the complexity of change in the built environment. The archival studies allow us to gauge the impact of the energy subsidies, while the interviews make it possible to understand the conservation planning practises of today. The comparative method enables a more generalised understanding of the drivers behind changes in the built environment. It provides an opportunity to determine whether differences are evident between municipalities or between areas of various heritage values, thereby indicating to what degree national policies and local practise affect the built environment.

\section{Energy-saving subsidies}

Energy saving measures is an agent of change that has been common in the built environment since the 1970s. From a national point of view, the reasons to implement energy efficiency measures have shifted from including goals for national independency from oil import to reduced dependency on nuclear power, reduction of the level of unemployment in the building sector and slowing down the pace of climate change. For the individual homeowner, energy efficiency measures can be the result of a desire to lower the heating cost, to improve the indoor climate or to become more environmentally friendly.

Energy subsidies for buildings were first introduced in Sweden in 1974 as a result of energy-saving targets set by parliament (Proposition 1974:69). The overarching goal of the 
policy, which also was reached in a ten-year period, was to make the Swedish society, and particularly the building stock, much less dependent on oil by increasing the nation's energy efficiency. Energy use in buildings was to decrease between 39 and 48 TWh, or about 25 per cent. By 1985, Sweden had gone from being one of the most oil-dependent countries in Europe to becoming one of the least dependent. The goal was reached partly by using energy more efficiently and partly by a turn towards more use of electricity for heating. (Kander et al.,2013) When looking at major shifts in energy use, the period 1970-1985 stands out as one in which a centralised welfare-state determined to modernise society could point out a direction of development and work to realise it by introducing policies that would have a huge impact.

Measures entitled to subsidies were, e.g. new heating system, additional insulation, new windows and adjustments of boilers and radiators (Bostadsstyrelsen, 1984). During the ten years, 504,327 applications were approved at a total cost of SEK7.4bn, of which 26 per cent were grants and 74 per cent were loans. Subsidies were calculated based on fixed costs for different measures.

In Sweden, energy subsidies were, especially in the late 1970s and early 1980s, criticised for being insensitive to architectural values in the built environment. (Legnér and Leijonhufvud, 2019) Following the aim of relating energy-saving measures to architectural values in the built environment, this study is limited to grants for external measures, i.e. additional façade insulation and new windows. In 1977/1978, external measures accounted for c. 89 per cent of approved costs for single-family buildings, a number that subsequently declined to c. 37 per cent in 1982/1983 because the criteria that had to be met to receive a loan were sharpened. For multi-family buildings, the share was steady at c. 50 per cent (Bostadsstyrelsen, 1984, p. 26). The single most supported measure was additional thermal insulation. In time, this proved to be the least profitable measure. Many houses that were retrofitted did just receive the minimum thickness of insulation allowed or even less (Bostadsstyrelsen, 1984, p. 94; Antell and Paues, 1981, p. 24).

This study looks at the impact on buildings of measures supported by energy subsidies in the three identified urban areas. Archives documenting the energy subsidies have in many regions been deaccessioned, and the policy has evidently left little traces in building permits. Almost four decades have passed since those measures were taken, and ocular inspection is the only certain way of finding out what was actually done on a certain building. Many measures taken with energy subsidies in the 1970 and 1980s are still completely visible in the urban environment.

\section{Case studies}

With a population of 85,000, Gävle is a mid-size Swedish town. The studied area in Gävle comprises 69 single- and multi-family detached houses built in the district Brynäs in the midwar years and 1950s. Four blocks were constructed in the 1920s, originally as three- or fourfamily houses, although most of them today are used as single-family houses. Most of the houses from the 1930 to 1950s were originally two-family houses, today used by one family. The architectural styles of the buildings, as well as how they are situated on the plots, changed after the 1930s, resulting in a difference in character between the northern and southern parts. The area was predominantly working class, and the buildings were developed and owned by the residents themselves. In today's urban plan, the older part of the area has been given the highest value. The reason is the structure of buildings and their design, which is typical for wooden houses from the 1920 and 1930s, but also for the adaptation to terrain and the vegetation. The comprehensive plan of Gävle designates the northern part of the area as having cultural values ("kulturvärden") "of great importance", and that maintenance and reconstruction should be done in a traditional manner (Gävle Municipality, 2009) None of the properties is listed. 
The population of Visby is c. 23,800, which makes it a small town in Sweden. The second area, Visby villastad, has been chosen for its similarities with the area in Brynäs. Both areas are located close to the city centre, dominated by owner-occupied detached houses, with an addition of a few smaller multi-family houses. In this sense, they are very similar to other urban areas in Sweden dominated by older, detached houses. They were both built up in the first half of the $20^{\text {th }}$ century as homes for working-class families. The area in Visby villastad is located around Polhemsgatan, just outside the city walls, and comprises 38 single-family detached houses with individual gardens. The area was constructed in the 1930 s adjacent to the town's slaughterhouse, as housing for its workers. The comprehensive plan of Visby designates the cultural values in the area as "particularly valuable" (Gotland Municipality, 2009). None of the properties is listed.

The third area, also in Visby, is located in the medieval city centre. It consists, like the other areas, of owner-occupied detached houses and a few smaller multi-family houses. The area contains 29 properties with buildings erected between the $18^{\text {th }}$ and the early-21 $1^{\text {st }}$ century, with some remains of medieval buildings integrated in newer ones. The area is divided by a steep cliff, with the larger part of the block located below the cliff. On the cliff, there has historically been smaller wooden houses, and below, there have been more well-off households with masonry houses. This difference in building style is still today visible. The northwest part, located beneath the cliff, runs along St. Hansgatan, which was the most attractive street in town in the $19^{\text {th }}$ century. This part of the block is dominated by larger $19^{\text {th }}$. and $20^{\text {th }}$-century buildings (the most recent from the 1970s and 1980s), but there are also four buildings from the $18^{\text {th }}$ century. The southeast part of the block, on top of the cliff, stretches along the square Kinbergs plats and the narrow street Björngränd, and is dominated by small $18^{\text {th }}$-century houses. In the north, the houses are larger, and most of them from the $19^{\text {th }}$ century, except for a large residential building erected in 2007. The area is part of the World Heritage Site (WHS) of the Hanseatic Town of Visby (designated in 1995) and as such, considered to have cultural values of great importance on a global scale. Three of the properties are listed.

A comparison between these areas allows us to comment on whether changes in the built environment can be derived from national policies (if all three areas exhibit similarities), local policies (if the areas in the same municipality exhibits similarities) and if cultural aspects considered valuable were considered (if Visby intramural stands out).

\section{Results}

\subsection{Energy-saving policy}

The rate of approved energy saving subsidies differs clearly between the studied areas. In 1974-1984, 47 subsidies were accepted for the studied area in Brynäs consisting of 69 properties, or 0.68 per property. In the area studied in Visby villastad, consisting of 38 properties, 17 subsidies were accepted, or 0.45 per property. The area in Visby intramural, consisting of 25 properties, was assigned eight subsidies, or 0.32 per property. Thus, Brynäs had more than twice as high rate as Visby intramural (Table 1).

The pattern is enhanced regarding the rate of completed energy retrofits. Since 1974, additional external insulations have been completed in 58 buildings in Brynäs (84 per cent), 17 in Visby villastad (45 per cent) and two in Visby intramural (7 per cent). In the same period,

\begin{tabular}{lll}
\hline Brynäs & Visby villastad & Visby intramural \\
\hline $47(0.68 /$ property $)$ & $17(0.45 /$ property $)$ & $8(0.28 /$ property $)$
\end{tabular}

Table 1. Approved subsidies for additional insulation or new windows 1974-1984 
new windows have been installed in 50 buildings ( 72 per cent) in Brynäs, 18 buildings ( 47 per cent) in Visby villastad and six buildings (21 per cent) in Visby intramural. Energy retrofits were significantly more common in Brynäs than in Visby and more common in Visby villastad than in the intramural. In areas with a higher number of approved subsidies, completed retrofits are more common. In both Brynäs and Visby villastad, more retrofits were made than subsidies approved, indicating that energy efficiency measures were completed, regardless of the policy measure. The fact that the discrepancies are bigger for completed retrofits than for provided subsidies possibly indicates that completed retrofits (in some cases, results of subsidies) acted as catalysts for further measures in the area (Table 2).

For different reasons, applications for energy subsidies could be denied. Reasons for denial included sufficient current insulation, lacking financial security or that the measure was considered too small. One example of the latter was the rejection of an application from the property owner of Rapphönan 4 in October 1974, for installing additional façade insulation. The application was denied because of the planned insulation being too thin, $30 \mathrm{~mm}$ (Archive of the Regional Housing Committee in Gotland, 1974, 7 October). The guidelines for the regional housing committees stated that the subsidy must result in significant energy savings. Regarding additional thermal insulation, this was calculated from the thickness of the material. At least $100 \mathrm{~mm}$ was required for approval of an application (Bostadsstyrelsen, 1984, p. 62). Negative effects on architectural values were not considered by the housing committee, just whether the measure reached the instrumental criteria of the policy or not. This aspect is key to understanding why it often was possible to carry out major exterior changes of a house without first getting approval from the municipality.

Few of the energy retrofits conducted in the studied areas had approved building permits, even though this, in theory, should have been required for major exterior alterations. In Brynäs, 34 per cent of the completed retrofits had approved permits, in Visby villastad, 20 per cent, and in Visby intramural, 38 per cent. In total, c. 31 per cent of the completed additional façade insulations and installations of windows had received a building permit (Table 3).

The differences in energy retrofits between the areas are also qualitative. Additional insulation and new windows can be installed in various ways, with more or less concern for present character of the building. Measures can completely alter the character of a building, they can affect just a small part or they can harmonise with the original idea. Furthermore, they can increase the original character of the building by improving previous alterations. The three areas have all experienced transformational changes since 1974, but to a varying degree. As the following examples show, more care has been taken with cultural values in Visby intramural than in Visby villastad, where, in turn, greater care has been taken than in Brynäs.

Table 2.

Completed energy retrofits since 1974

\begin{tabular}{llll}
\hline & Brynäs & Visby villastad & Visby intramural \\
\hline Additional insulation & $58(0.84 /$ property $)$ & $17(0.45 /$ property $)$ & $2(0.07 /$ property $)$ \\
New windows & $50(0.72 /$ property $)$ & $18(0.47 /$ property $)$ & $6(0.21 /$ property $)$ \\
Total & $108(1.57 /$ property $)$ & $35(0.92 /$ property $)$ & $8(0.28 /$ property $)$ \\
\hline
\end{tabular}

Table 3 .

Approved building permits. Percentage of completed retrofits

\begin{tabular}{lccc}
\hline & Brynäs & Visby villastad & Visby intramural \\
\hline Additional insulation & $16(28 \%)$ & $4(24 \%)$ & $0(0 \%)$ \\
New windows & $21(42 \%)$ & $3(16 \%)$ & $3(50 \%)$ \\
Total & $37(34 \%)$ & $7(20 \%)$ & $3(38 \%)$ \\
\hline
\end{tabular}


In 1978, the property Berget 16 in Visby intramural, today a listed building, received funding for additional insulation on the southern façade. Photographic material from the time shows the work in progress. Today, the additional insulation is clearly visible, and the plaster differs from the rest of the building. The same year, Berget 19 received funding for additional insulation of the system of joists. It is visible from the outside as a metal sheet covering the lower joists in a gateway to the yard. These are the only two measures in the studied area in Visby intramural that have been confidently derived from energy subsidies. They are also two of the most notable energy measures in the area. Even though the measures in the two buildings are clearly visible and somewhat alter the character of the buildings, they are both limited to defined spaces in the façade and do not alter the building much. None of the measures was dealt with in building permits. Evidently, the policy had an insignificant impact on the historic environment in the block Berget. But, the two examples also demonstrate that somewhat extensive measures to buildings' exteriors could be carried out without a building permit. Probably more so during the earlier period of the investigation, as the number of measures demanding permits increased with the rising interest in the cultural values in Visby, most noticeable after the designation to WHS in 1995.

A number of properties in the studied area in Visby villastad installed additional insulation and new windows during the 1970s and 1980s. As an illustrating example, five out of ten buildings in the block Näktergalen have similar changes to the façades: new white bricks on the original wood with an insulation material in between. The five houses are adjacent to each other. The additional thickness of the façade gives the buildings a heavier appearance, leaving windows and base c. $100 \mathrm{~mm}$ further in than the brick facade. The fact that so many buildings have additional insulation and new windows significantly alter the character of the area. Still, some of the original architecture in Visby villastad has been preserved. For example, the original single-s roof tiles are kept. Also, the fact that many of the buildings have changed in the same manner (e.g. additional white brick façade) preserves the character of a cohesive area, although not with original character.

Brynäs has the highest share both of approved energy subsidies and completed energy retrofits. It is also the area where the original character is most altered. Of course, the high ratio of alterations is an important factor, but also the nature of completed measures. Many façades have been applied with a thick layer of additional insulation and with façade materials strongly deviating from the original, such as metal sheet, roughly sawn wooden panels and bricks. Little care has been given to details such as transitions between structural elements, e.g. around windows and above sockets. Both the crude implementation and the large variety of solutions contribute to the impression of an area where at least architectural values are no longer actively managed.

\subsection{Conservation practice}

In the following, the conservation practice in the areas will be examined, based on local policy documents and interviews with planning officials. Before 1987, a building was regulated in the Building Act of 1947, later complemented by the Building Code of 1960 (Statens Planverk 1976). The Swedish Planning and building Act from 1987 states that all changes to a building must be done with caution to the building's character in regard to technical, historical, cultural, environmental and artistic/architectural values. Particularly, valuable buildings, such as those in the studied areas, must not be altered (SFS 2010:900, chapter 8, $13 \S \mathrm{PBL}$ ). In the comprehensive plans, all three areas are described as having important cultural values. The study argues that the compliance of conservation practice with the comprehensive plans and the Planning and Building Act varies with the extent of completed energy retrofits.

6.2.1 Brynäs. The detached houses in Brynäs were surveyed by the county board of administration in 1979 to document the changes made to them because of the improvements 
in energy efficiency (Nordin, 1979, p. 7). The surveyors concluded that the character of these houses was worth preserving, but that substantial changes had taken place in a very short period, and that additional changes were expected to occur because of favourable energysavings policies. "Substantial changes" were equal to the changes in the material of façades, or if the appearance of the new façade deviated strongly from the surrounding houses in its colour, surface or details. The current comprehensive plan for Gävle states that the northern part of the studied area, originating in the 1920s, has a character typical for its age, because of the placement and design of the buildings and therefore considers it to have important cultural values. Refurbishments and maintenance shall be conducted in a traditional fashion (Gävle Municipality, 2009, pp. 96-97). The evaluation is based on the extent of preserved original characteristics in an area (Gävle Municipality, 2009, p. 6.), i.e. on ideas of originality. Handling of planning and permits shall, according to the general plan, be referring to the Planning and Building Act, Chapter 3, §12, discussed above (Gävle Municipality, 2009, p. 97).

Interviews with planning officials in Gävle provide a stark contrast to the wordings of the general plan. In practice, neither the municipality nor the county administration have acted on the developments in the area. Planning officials are not satisfied with how the area has developed over the past half century. While walking in the area together with the planning officials, we discovered ongoing extensions and refurbishments, carried out without building permits. The municipal architect argued that signs of the buildings originating in the same era are lost because of the many changes in shape, colour and material. The interviewees were all in agreement that new windows and façades, and particularly additional façade insulation, had affected the character of the buildings in the area negatively and derived many of the measures to the energy subsidies of the 1970s and 1980s. Despite this, large parts of the area are designated as having "important cultural values" in the comprehensive plan, and are subject to the paragraph of the Planning and Building Act stating that it must not be altered (Gävle Municipality, 2009, p. 97). In practice, these policy measures prove ineffectual.

An issue highlighted by several of the participants in Gävle was the "inflation" of retrofits. Measures that, in theory, require a permit, and that previously were generally accepted as such, are now regarded among property owners as "small" measures. For example, it has become part of "normal" maintenance to change the windows in buildings, something that many property owners do without the knowledge of the municipality. The participants all agreed that this led to an "inflation" of sorts; in an area affected by extensive and insensitive retrofits in the past, less care is taken to architectural values. This attitude undermines the ability of local policies; if local officials are not informed of measures in the environment, wellintended formulations in policy documents are of no use. Even when matters reach permit administrators in Gävle, it is not certain that any values are accounted for. The municipal conservation officer questioned if administrators were willing to fight for cultural values when an area is already in decline.

6.2.2 Visby villastad. According to the cultural heritage appendix to the comprehensive plan of Visby, the studied area in Visby villastad is considered to have particular cultural values (Gotland Municipality, 2009). This entails that handling of planning and permits shall refer to the Planning and Building Act, Chapter $3, \S 12$, hindering alterations of the character of the area. Despite this, and much like in Brynäs, the interviewed planning officials are highly critical to the way the area has developed, with many character-changing alterations. One of the interviewees had been working with building permits in this area already in the late 1970s and could tell about the requirements for permits at the time. He explained that the historical values of the inner city were recognised already then, even if they still were not so well protected in legislation.

Even though the area has particular cultural values according to the comprehensive plan, none of the four planning officials that were interviewed considered changes of façades and windows to be subject to building permit. As in Brynäs, the reason for this is the many 
previous changes in the area. The city architect argued that changes can be managed using permits in areas with a strong consistency in the built environment, but that this is not the case in Visby villastad. On the contrary, it is difficult to pinpoint which tangible elements of the environment carry cultural values in the area. The many changes being carried out make it difficult to argue that an individual building is of importance for the perception of the whole area. One of the interviewed planning officials regretted how often they are forced to accept measures:

Very often people ask whether a measure would be subject to permit audit. If it is a beautiful building and the last one on the street to have e.g. original windows, you think "no, do not do it!" But when all other houses have been subject to change, it is difficult to argue for a duty to apply for a permit.

If the original character of the area had been preserved, one interviewee argued, cultural values would be more apparent. This would make it easier to hinder further unwanted measures: "It is much more difficult when changes have gone this far and there are only a few buildings left with the original character".

Much like in Brynäs, planning officials experience that they have very little influence over the environment in Visby villastad. All interviewees agreed that this is due to the many previous changes in the area, and that the regulatory framework hinders effective heritage planning in areas that are already altered. We suggest that this perception comes rather from entrenched practice than from how the jurisdiction is formulated. The Building and Planning Act dictates that all changes to a building must consider its original character, in particular if the area is designated as having important values. Despite this, there is today very little planning officials do to preserve remaining cultural values in the area.

6.2.3 Visby intramural. Following years of surveying of buildings inside the medieval city wall of Visby, an action plan was presented by the municipality in 1973. By this time, only 15 houses were legally protected as historic monuments, but in the plan, an additional 55 houses were identified as having great historical value, whereas another 415 houses had at least some historical values (Gotland Municipality, 1973, pp. 14-15). This was a recognition of the cultural heritage of the inner city that would be important for future guidelines and management of the built environment. The maps displaying the historical values were an important tool not least for officials handling building permits, but were also available to house-owners on request. Guidelines for how owners should approach houses in the intramural part of the city were, however, not published until 1989 (Gotland Municipality, 1989).

Local policy documents consider the whole area of Visby intramural to have particular cultural values (Gotland Municipality, 2010a, p. 7). Since 1995, it is also designated as a UNESCO WHS, hence considered valuable for its contribution to the history of mankind. The heritage values of the area are highlighted in the local policy "Guidelines for Visby intramural" (Gotland Municipality, 2010b). It states that "heritage values are the base for all development, management and care in the built environment" (p. 37). This means that other values, such as energy performance, are downplayed:

Demands made by society in conjunction with refurbishment, concerning e.g. energy efficiency, ventilation and accessibility, are in Visby intramural to be applied with respect to the cultural values of the built environment. This means that demands in some cases must be lowered in favour of cultural values ("Byggnadsordning för Visby innerstad" 2010b, p. 35).

Even smaller changes are advised against, because in the long run, they are at risk of diminishing the "notion of authenticity" in the area. Many small changes tend to alter the "authenticity, readability and attraction" of the town ("Byggnadsordning för Visby innerstad" 2010b, p. 37). It is worth noting how intimately the concepts of "authenticity" and "attraction" are connected. This is also explicit in the guidelines, stating that "there is an 
obvious connection between the cultural values in the town and the financial values of the properties [...] Property prices and solvency are higher in areas with important cultural values" ("Byggnadsordning för Visby innerstad” 2010b, p. 11).

Permit administrators are highly aware of the cultural values in the environment in Visby intramural. Just as the guideline proposes, other values are sacrificed to maintain the character of the area. The interviewed planning officials all agreed that almost all external changes to buildings in Visby intramural are subject to audit, and very few changes are permitted. But, contrary to the guidelines, the notion of originality is downplayed among the planning professionals in favour of the values of the changing character of the area. As one interviewee said: "It is often like that in Visby intramural, that the buildings have changed character. It is often very difficult to determine the age of the buildings because of the many extensions and refurbishments." This is described by the planning officials as one of the key characters of Visby intramural: "The development is part of the character; it shows the different ages of the town. This is an aspect worth taking advantages of [...] It is the actual building pattern, that each era has made its mark. This is a value in itself". Contrary to Brynäs and Visby villastad, change is here seen as a value, as development rather than degeneration.

Nevertheless, when it comes to building permits, it is still evident that authenticity and originality in the built environment in Visby intramural are highly valued by the municipality. For example, a property owner who applied for a permit to change the windows in his $19^{\text {th }}$-century stone house in 2015 stated that the reasons were increased aesthetical values, better energy efficiency, better sound-proofing and less maintenance (building permit archive in the Gotland regional archive. Berget 21, 2015-6253). The applicant had a conservation consultant make an evaluation and suggest the design of the new windows, which were to be hand-made and mimic the original design. Nonetheless, the permit was denied to protect heritage values. The objection from the municipality was that the suggested outer glass was too thick and did not meet the aesthetic requirements. The municipality regarded the measure as likely to improve the energy efficiency and soundproofing, but because of the changes in the environment that thicker window glass would lead to, they denied the application. The homeowner, on the other hand, did not see the concerns as opposites, but as entangled, and argued that the solution would give the overall best result. (For a similar discussion, see Sunikka-Blank and Galvin, 2015.)

Unlike in Brynäs and Visby villastad, planning officials in Visby intramural experience that they have the means to influence changes in the environment. However, this does not seem to be a result of the "original" character in the area. On the contrary, the interviewed planning officials highlighted the values of an environment that has developed over time. So, change was in Brynäs and Visby villastad used to explain why the municipality cannot preserve buildings, and in Visby intramural, to explain the unique character of the area and the need for continuous heritage conservation.

\section{Conclusions and policy implications}

By comparing the share of approved applications, as well as completed energy retrofits, this study demonstrates that the effects of the national energy subsidy policy differed significantly between urban areas. Areas with a high degree of approved subsidies also had a high degree of retrofits, suggesting that the policy had intended effects. In these areas, the number of retrofits were also significantly higher than the number of subsidies. This was not the case where energy subsidies were fewer, which indicates that energy retrofits may be performative, meaning that they could be accelerating further retrofits in the same area.

This hypothesis is supported by the results of interviews with local planning officials and our study of policy documents. In the two areas that were most affected by energy retrofits in the past, all interviewees expressed a connection between extensive retrofits made in the past 
and the municipality's ability to control the current development. Areas affected by extensive retrofits in the past are managed in less detail, leaving existing policy measures on both energy and heritage untapped. Slow development, on the other hand, may have the opposite effect.

The explanation seems to be related to practice rather than legislation. The Swedish Planning and Building Act from 1987 states that all changes to a building must be done with caution to the building's character in regard to technical, historical, cultural, environmental and artistic values. Particularly, valuable buildings, such as those in the studied areas, must not be altered (Plan- och bygglagen 1987, tredje kapitlet $\S 10, \S 12$. SFS 2010:900, 8 kap. $17 \S$ $\mathrm{PBL}$ ). However, based on interviews with local planning officials, this study demonstrates that buildings in areas with a large share of completed energy retrofits clearly seem to be less likely to be protected based on the Planning and Building Act, even if the character of the individual building has been preserved. The findings indicate a threshold effect: areas subject to extensive change in the past are seemingly given less attention by urban planners today.

The concept of change itself, however, seems to be valued differently in different areas. In both Brynäs and Visby villastad - areas from the early $20^{\text {th }}$ century that are culturally valued, but not strongly protected - the local planning officials repeatedly expressed ongoing and previous changes as a decline of the original character, as it is expressed in building plans and a previous survey. In Visby intramural - an area with medieval origins and protected as a WHS - the continuous change over the course of history is rather expressed as a value in itself, and part of an organically developing urban landscape. This is a puzzling finding, given that an area protected in official policy documents, including international ones, could be expected to be preserved more rigorously. Of course, this is partly a result of the quantity and quality of change in the respective areas. Change is easier to accept if carried out with moderation and care for the existing character. Possibly, it is also a result of a desire to, and a habit of, treating the area as historically significant. As Visby intramural today is designated as a WHS and considered more or less unique by conservation experts, all previous activity is considered to be a part of this unique place and its development and is therefore expressed as heritage values. In Visby, there is also a tradition going back to the early post-war years to treat the intramural area as a cultural heritage. In areas with less protection and less official cultural importance, there is less of a habit of treating the area as historic. In the eyes of the interviewees, there is a tendency to regard modern development in these areas as a decline of the character of the built environment.

Also, regarding energy efficiency aspirations, previous changes in the environment have had unintended and unexpected long-term effects. Paradoxically, large investments in energy efficiency in the 1970s and 1980s may hinder further improvements. As changes to façades and windows are not subject to permit inspection in areas that have undergone extensive change, officials have no way of influencing the choices of the property owner and can therefore not work towards neither a conservation of architectural values nor reduced energy use. Except for the information provided by energy audits, there are no policies in effect considering existing buildings that can contribute to reach national and international energy targets. Thus, in the way planning officials work today, ambitious targets for energy saving will be difficult to reach.

Admittedly, this is a limited study concerning two Swedish municipalities. It is not clear whether the findings can be applied on a wider scale, nationally in Sweden or internationally. Furthermore, it is limited to one specific policy measure, energy-saving subsidies provided in the 1970s and 1980s. The generalisability of the findings may, therefore, be limited. Despite this, the findings provide an important indication of the relationship between energy-saving policies in the past and urban planning practice of existing urban areas today, as well as the importance of alignment between policy-making and implementation. 
In conclusion, this indicates that policy instruments for the building stock and the practice of conservation planning have not worked well together. Due to local practice, energy subsidies provided in the 1970s and 1980s still today have a negative effect on both heritage conservation and energy efficiency in existing areas. It should, however, be noted that this is the opinion of professionals working in the local government with building and planning. Homeowners themselves and the general public may have other views.

Finally, there is a discrepancy between expectations and outcome of policy measures. National decision-makers overestimate the possibilities to control the development on a local level, for both energy efficiency and architectural values. May a gradual increase in the energy efficiency of the building stock be more sustainable and protective of its character than vast but short-lived policy programmes? This study, however limited, seems to support a slow but sustained and thoughtful approach to increased energy efficiency in buildings. By examining long-term effects and entanglements of policies and practice, this study contributes to a better understanding of the complexity of different values in the built environment.

\section{References}

Antell, O. and Paues, C. (1981), Isolering uppåt väggarna: en studie av tilläggsisolerade hus [Insulation up the walls: a study of additionally insulated houses], Riksantikvarieämbetet, Stockholm.

Archive of the Regional Housing Committee in Gotland (1974), (Gotlands Länsbostadsnämnd), Regional Archive of Gotland, October 7, Visby.

Berget 21, 2015-6253, Building Permit Archive in the Gotland Regional Archive, Visby.

Bostadsstyrelsen (1984), Bostadsstyrelsens Lån- Och Bidragsgivning till Energisparåtgärder I Bostäder $M m$, [Loans and Grants provided by the Board of Housing for Energy Saving Measures in Residential Houses etc.], Byggforskningsrådet, Stockholm.

Economidou, M., Laustsen, J., Ruyssevelt, P. and Staniaszek, D. (2011), "Europe's buildings under the microscope: a country by country review of the energy performance of buildings", Buildings Performance Institute Europe.

Energimyndigheten (2019), Basis for the Third National Strategy for Energy Efficient Renovation. (Underlag till Den Tredje Nationella Strategin För Energieffektiviserande renovering), Boverket och Energimyndigheten, Karlskrona.

Femenías, P., Wahlgren, P., Johansson, P., Thuvander, L. and Eriksson, P. (2020), Om-renovering möjligheter för energieffektivisering när äldre bostadshus renoveras en andra gång, Chalmers Tekniska Högskola, Rapport ACE 2019:13, Göteborg.

Gävle Municipality (2009), Heritage Supplement for the General Plan of Gävle 2025 (Kulturmiljöbilaga till Översiktsplan För Gävle Stad 2025), Gävle kommun, Gävle.

Geller, H., Harrington, P., Rosenfeld, A.R., Tanishma, S. and Unander, F. (2006), "Policies for increasing energy efficiency: thirty years of experience in OECD countries", Energy Policy, Vol. 34, pp. 556-573.

Gotland Municipality (1973), Visby. Action Plan for the Intramural City. (Visby. Handlingsplan För Staden Inom murarna), Gotland Municipality, Visby.

Gotland Municipality (1989), Visby Inner City. Guidelines for Conservation. (Visby Innerstad. Råd Och Riktlinjer För bevarande), Gotland Municipality, Visby.

Gotland Municipality (2009), The Character of the Built Environment in Visby, 1900-2000. (Hela Visby: Bebyggelsens Och Utemiljöns Karaktärsdrag I Visby Ytterstad 1900-2000. Bilaga till Fördjupad Oversiktsplan För Visbyområdet, Antagen Av Kommunfullmäktige), 2009-12-14, § 172, Gotland Municipality, Visby.

Gotland Municipality (2010a), Urban Plan for Visby Intramural. (Detaljplan För Visby Innerstad Gotlands Kommun), Antagen 2010-02-22, Gotland Municipality, Visby. 
Gotland Municipality (2010b), Guidelines for Visby Intramural. (Byggnadsordning För Visby Innerstad), Gotland Municipality, Visby.

Govt. Bill 2016/17:146, A National Climate Policy Framework for Sweden. (Ett Klimatpolitiskt Ramverk För Sverige), Swedish Parliament, Stockholm.

Kander, A., Malanima, P. and Warde, P. (2013), Power to the People: Energy in Europe over the Last Five Centuries, Princeton University Press, Princeton.

Legnér, M. and Leijonhufvud, G. (2019), "A legacy of energy saving: the discussion on heritage values in the first programme on energy efficiency in buildings in Sweden, c. 1974-1984", The Historic Environment: Policy and Practice Vol. 10 No. 1, pp. 40-57.

Mallaburn, P. and Eyre, N. (2014), "Lessons from energy efficiency policy and programmes in the UK from 1973 to 2013”, Energy Efficiency, Vol. 7, pp. 23-41.

Nordin, E. (1979), Energy Saving Loans and Renovation of Facades (Energisparlån Och Fasadombyggnader. En Provstudie Av Åtta Kvarter På Brynäs), Gävleborg County Board of Administration, Gävle.

Proposition 1974:69, Proposition on Measures for Energy Savings. (Kungl. Maj:ts Proposition Angående Vissa Energibesparande Atgärder), Swedish Parliament, Stockholm.

Riksantikvarieämbetet (2017), Cultural values in planning and building permit prcoesses (Kulturvärden i planerings- och bygglovsprocesser - en utvärdering om kommuners förutsättningar att ta hänsyn till kulturvärden), Riksantikvarieämbetet, Stockholm.

Riksantikvarieämbetet (2018), Kulturvärden Försvinner I Byggprocessen. Intervjuer Och Aktgranskning I Bygglovsärenden, Riksantikvarieämbetet, Stockholm.

Rosenow, J., Fawcett, T., Eyre, N. and Oikonomou, V. (2016), "Energy efficiency and the policy mix", Building Research and Information, Vol. 44 Nos 5-6, pp. 562-574.

Rosenow, J. (2012), "Energy savings obligations in the UK - a history of change", Energy Policy, Vol. 49, pp. 373-382, ISSN 0301-4215.

Sandberg, N.H., Bergsdal, H. and Brattebo, H. (2011), "Historical energy analysis of the Norwegian dwelling stock", Building Research and Information, Vol. 39 No. 1, pp. 1-15, doi: 10.1080/ 09613218.2010 .528186$.

SFS 2010:900, Chapter 8, 13 \& PBL. The Swedish Planning And Building Act, Swedish Parliament, Stockholm.

SOU 2017:2, Mustering for Future Energy. (Kraftsamling För Framtidens Energi), Statens Offentliga Utredningar, Stockholm.

Statens Planverk (1976), Guidelines for Handling Matters of Planning and Building (Anvisningar För Handläggning Av Plan- Och byggnadsärenden), Statens Planverk, Stockholm.

Sunikka-Blank, M.M. and Galvin, R. (2015), "Irrational homeowners? How aesthetics and heritage values influence thermal retrofit decisions in the United Kingdom”, Energy Research and Social Science, Vol. 11, pp. 97-108, doi: 10.1016/j.erss.2015.09.004.

Tunefalk, M. and Legnér, M. (2019a), "Decision-making on a national home improvement programme in Sweden and its effects on the built environment, 1984-1993”, The Historic Environment: Policy and Practice, Vol. 10 No. 2, pp. 106-121, doi: 10.1080/17567505.2019. 1549397.

Tunefalk, M. and Legnér, M. (2019b), "Long-term effects of additional insulation of building façades in Sweden: towards a holistic approach", International Journal of Building Pathology and Adaptation, Vol. 38 No. 2, doi: 10.1108/IJBPA-02-2019-0020.

Vine, E. (2008), "Strategies and policies for improving energy efficiency programs: closing the loop between evaluation and implementation", Energy Policy, Vol. 36, pp. 3872-3881.

Webb, A. (2017), "Energy retrofits in historical and traditional buildings: a review of problems and methods", Renewable and Sustainable Energy Reviews, Vol. 77 No. 2017, pp. 748-759. 
About the authors

Mattias Legnér is a Full Professor in Conservation and Docent in History at Uppsala Universitet Campus Gotland. Since 2010, he has written extensively on the historical development of energy use in buildings, especially how improvement in energy efficiency relates to cultural values in the built environment. He has led three large research projects funded by the Swedish Energy Agency, currently heading the project "Energy efficiency and cultural values in the housing stock. How well do policies work on the local level?" 2020-2023 (Project \#54001-1). Mattias Legnér is the corresponding author and can be contacted at: mattias.legner@konstvet.uu.se

Gustaf Leijonhufvud is a Researcher in Conservation at Uppsala Universitet Campus Gotland. His $\mathrm{PhD}$ thesis Decision making on indoor climate control in historic buildings: knowledge, uncertainty and the science-practice gap was published at Göteborg University in 2016. He continues to explore issues of indoor climate and energy efficiency in historic buildings.

Martin Tunefalk took his $\mathrm{PhD}$ in History at Stockholm University in 2015. He is currently working at the National Historical Museums in Stockholm.

For instructions on how to order reprints of this article, please visit our website:

www.emeraldgrouppublishing.com/licensing/reprints.htm

Or contact us for further details: permissions@emeraldinsight.com 